\title{
Abbreviations and variables
}

\begin{tabular}{|c|c|}
\hline AA & advanced aggregator \\
\hline $\mathrm{ABB}$ & Asea Brown Boveri \\
\hline ABM & agent-based modelling \\
\hline ANR & $\begin{array}{l}\text { Agence Nationale de la Recherche; French National } \\
\text { Research Agency }\end{array}$ \\
\hline APP & $\begin{array}{l}\text { sector-level appropriability conditions, measured as } \\
\text { share of innovating companies in a sector indicating } \\
\text { that competitors provide important information input } \\
\text { to innovation }\end{array}$ \\
\hline $\mathrm{BIO}$ & (Uppsala) Biotechnology Initiative \\
\hline CEE & Central and Eastern European countries \\
\hline $\mathrm{CEO}$ & chief executive officer \\
\hline CIS4 & Fourth Community Innovation Survey (Norway) \\
\hline CMEs & $\begin{array}{l}\text { coordinated market economies (cf. Hall and Soskice, } \\
\text { 2001) }\end{array}$ \\
\hline CNRS & $\begin{array}{l}\text { Centre National de la Recherche Scientifique; French } \\
\text { National Centre for Scientific Research }\end{array}$ \\
\hline CRIT & Centre for Research, Innovation and Technology \\
\hline CURE & $\begin{array}{l}\text { corporate culture and regional embeddedness } \\
\text { (a European joint project funded by the European } \\
\text { Commission in the 6th framework programme) }\end{array}$ \\
\hline D_SYN & $\begin{array}{l}\text { dummy variable indicating synthetic }(=1) \text { or analytic } \\
(=0) \text { knowledge bases }\end{array}$ \\
\hline DGEO_EU & $\begin{array}{l}\text { variable capturing the number of different collaboration } \\
\text { partners used in other (non-Nordic) European countries }\end{array}$ \\
\hline DGEO_ND & $\begin{array}{l}\text { variable capturing the number of different } \\
\text { collaboration partners used in other Nordic } \\
\text { (Norway excluded) countries }\end{array}$ \\
\hline DGEO_NO & $\begin{array}{l}\text { variable capturing the number of different } \\
\text { collaboration partners used in Norway }\end{array}$ \\
\hline DGEO_SCI & $\begin{array}{l}\text { variable capturing the geographical diversity } \\
\text { (number of world regions) of science system } \\
\text { collaboration }\end{array}$ \\
\hline
\end{tabular}




\begin{tabular}{|c|c|}
\hline DGEO_US & $\begin{array}{l}\text { variable capturing the number of different } \\
\text { collaboration partners used in the USA }\end{array}$ \\
\hline DGEO_VER & $\begin{array}{l}\text { variable capturing the geographical diversity } \\
\text { (number of world regions) of customer and supplier } \\
\text { collaboration }\end{array}$ \\
\hline EPO & European Patent Office \\
\hline ERIS & entrepreneurial regional innovation system \\
\hline EU & European Union \\
\hline EXPSHR & export share \\
\hline FDI & foreign direct investment \\
\hline GDP & gross domestic product \\
\hline GE & General Electric \\
\hline GM & General Motors \\
\hline GMO & genetically modified organism \\
\hline GOVERD & governmental expenditures on $\mathrm{R} \& \mathrm{D}$ \\
\hline GPN & global production networks \\
\hline GVC & global value chains \\
\hline HAMNO & $\begin{array}{l}\text { dummy indicating that no factors hampering } \\
\text { innovation activities are stated }\end{array}$ \\
\hline HERD & higher education expenditures on R\&D \\
\hline HQ & headquarters \\
\hline HR & human resources \\
\hline ICC & international chamber of commerce \\
\hline ICT & information and communications technology \\
\hline IDA Ireland & Industrial Development Agency Ireland \\
\hline INTMARKT & share of sales on foreign markets \\
\hline IRIS & institutional regional innovation system \\
\hline ISC & integrated supply chain \\
\hline IT & information technology \\
\hline KIBS & knowledge-intensive business services \\
\hline LCCGs & local collective competition goods \\
\hline LEMP & size control, log of number of employees \\
\hline LMEs & liberal market economies (cf. Hall and Soskice, 2001) \\
\hline M\&A & mergers and acquisitions \\
\hline MHC & multi-home-based corporation \\
\hline MLP & multi-level perspective \\
\hline $\mathrm{MNC}(\mathrm{s})$ & multinational corporation(s) company(ies) \\
\hline MNE(s) & multinational enterprise(s) \\
\hline $\mathrm{NIH}$ & 'not-invented-here' syndrome \\
\hline NIS & national innovation system(s) \\
\hline NMS & $\begin{array}{l}\text { new member states of the EU (acceded in } 2004 \text { and } \\
\text { 2007) }\end{array}$ \\
\hline
\end{tabular}


NUTS nomenclature des unités territoriales statistiques; the

ODIP organizational decomposition of innovation processes

OEM original equipment manufacturer

OL

OLS

organizational learning

ORG_DM dummy indicating affiliation with a domestic

(Norwegian) multinational corporate group

ORG_FO dummy indicating affiliation with a foreign corporate group

ORG_FO_EU dummy indicating affiliation with a European

(Nordic countries excluded) corporate group

ORG_FO_ND dummy indicating affiliation with a Nordic

(Norway excluded) corporate group

ORG_FO_OT dummy indicating affiliation with a corporate group

based in other countries

ORG_FO_US dummy indicating affiliation with a US corporate group

PARC

Palo Alto Research Center

PHARE Poland and Hungary: Aid for Restructuring of the

Economies: a pre-accession instrument financed by the EU to assist the applicant countries of Central and Eastern Europe in their preparations for joining the EU

PROPAT patenting propensity

R\&D

research and development

REC

renewable energy corporation

RIS

RUV

regional innovation system(s)

S_EU

relative unit values

variable indicating the existence of a collaborative relationship with a parent group unit in another

(non-Nordic) European country

S_ND variable indicating the existence of a collaborative relationship with a parent group unit in another Nordic country

S_NO variable indicating the existence of a collaborative relationship with a parent group unit in Norway

S_US variable indicating the existence of a collaborative relationship with a parent group unit in the USA

SE science excellence

SEE South-Eastern Europe

SFI Science Foundation Ireland

SFIN Skåne Food Innovation Network 
SKIN

SPL

SSP

SUV

TNC

TPA

UK

V4

VoC
Simulating Knowledge Dynamics in Innovation Networks

Système productif local; productive local system social systems of production (approach)

sports utility vehicle

transnational corporation

The Packaging Arena

United Kingdom

Visegrád 4 countries (Czech Republic, Poland, Hungary and Slovakia)

varieties of capitalism (approach) 